\title{
Review of Wage Increase Indonesian Migrant Workers Domestic Sector in Taiwan
}

\author{
${ }^{1}$ Suryadia $^{a}$, Hennigusnia ${ }^{b}$, Ivan Lilin Suryono ${ }^{c}$, Firdausi Nuzulad, Baskoro \\ Putra Aditya ${ }^{\mathrm{e}}$ abcdePolicy Development Center, Ministry of Manpower of \\ Indonesia, Jl. Jenderal Gatot Subroto Kavling 51
}

\begin{abstract}
Indonesia is a country that places the largest number of migrant workers in Taiwan dominated by female workers with the majority working in the domestic sector. However, the minimum wage of domestic sector Indonesian Migrant Workers working in Taiwan has not increased since 2015 at NT\$ 17,000. In the meantime, the minimum wage for non-domestic workers increased annually until 2020 to NT\$23,800. In addition to that, the amount of overtime wages of NT\$ 567 is still small compared to the wages of local domestic workers. Novelty of this study is the composition of the model of adjustment of the minimum wage and overtime wage of Indonesian domestic workers in Taiwan based on academic studies. Wage adjustment using Prorate approach, namely domestic Indonesian Migrant Workers wages, is calculated using Taiwan's minimum wage increase growth approach starting from 2016 - 2020 and for overtime wages following the rules applicable in Taiwan Labor Standard Act Articles 24, 32, and 36. Over the past 4 years Taiwan's minimum wage has increased by $5 \%$ annually from 2017 to 2019 , and $3 \%$ in 2020. The minimum wage of the domestic sector Indonesian Migrant Workers if it follows Taiwan's minimum wage growth becomes NT\$20,222. Based on the calculation of the minimum wage, the overtime wage per day ( $\geq 8$ hours) is NT\$1,067.
\end{abstract}

Key words: domestic workers, minimum wage, overtime wage, migrant workers

\footnotetext{
${ }^{1}$ All the writers are main contributors
} 


\section{Introduction}

Indonesia is a country that places the highest number of migrant workers in Taiwan. The number of Indonesian Migrant Workers in Taiwan as of December 2019 amounted to 276,411 people, with 27.1 percent working in the non-domestic sector and 72.9 percent working in the domestic sector. Indonesia excels in the domestic sector followed by the Philippines and Vietnam, while for the non-domestic sector, Indonesian Migrant Workers are below Vietnam and Philippines. Most of Taiwan's Indonesian Migrant Workers is dominated by female workers (75 percent) with the majority working in informal sector, namely domestic workers and caregivers.

For Indonesian Migrant Workers who chooses to work abroad, certainly has hope that the wages / income he/she receive will be greater compared to if he worked in Indonesia. So, from the wages received, in addition to being able to meet his needs while working in Taiwan, it can also be used to meet the needs of his family in his home region of Indonesia. However, the standard for the minimum wage of domestic sector Indonesian Migrant Workers working in Taiwan has not increased since 2015 at NT\$ 17,000. Meanwhile, the minimum wage for nondomestic workers increases periodically every year, with a percentage increase in accordance with Taiwan's policies and regulations. As of January 1, 2020, the wages of non-domestic workers have increased to NT\$23,800.

In addition to the minimum wage, another problem is related to overtime wages. In the written employment agreement, domestic Indonesian Migrant Workers is entitled to 1 day off in 7 days or replaced with overtime wages. The amount of overtime wages is determined based on the total amount of wages for a month divided by 30 days i.e., NT\$17000/30 = NT\$ 567. This provision is not comparable to the weekly break time that must be sacrificed by Indonesian Migrant Workers. The amount of overtime wages needs to be adjusted as a reward for the weekly break time of the domestic Indonesian Migrant Workers.

At the 4th JTF Meeting, both Indonesia and Taiwan agreed to adjust wage increases for Domestic Indonesian Migrant Workers. However, there are different methodologies used to calculate the amount of wage increase. The Taiwan delegation refers only to the value of the Consumer Price Index (CPI) in Taiwan, where the average growth rate of Taiwan CPI in 2015 to 2018 is $3.4 \%$, so domestic sector wages will only increase by NT \$ 578 or the total to NT\$ 17,578. On the other hand, the Indonesian delegation requested that the calculation be based not only on CPI but also KHL standards in Taiwan. KDEI Taipei has submitted a document on the basis of calculating wage increases for Indonesian Migrant Workers in the domestic sector to Taiwan through letter No. 0416/TK/KDEI/IV/2019. Based on a review of the Living Component Standard (KHL) conducted by KDEI Taipei, it was obtained that the ideal figure for the proposed wage increase for Indonesian Migrant Workers in the domestic sector is NT\$ 20,000 . 


\section{Problems}

Referring to the information that has been described, the problem is:

1. The minimum wage of Indonesian domestic workers in Taiwan, needs to be reviewed.

2. Overtime wages of Indonesian domestic workers in Taiwan, need to be reviewed.

Study Objectives

This study aims to provide input on the issue of minimum wage and overtime wage of Indonesian domestic workers in Taiwan. Workers are entitled to one day off in seven days. If the worker is required to work on the holiday, the employer is obliged to pay the overtime salary with a certain calculation.

\section{Methodology}

The issue of wages is one of the talking points to review. This type of study uses a descriptive qualitative approach with a data source in the form of text that is characteristic of the emphasis on the process. The process is through facts, realities, symptoms and events that occur. The data source comes from secondary data in the form of documents, discussions and interviews. With reference to economic developments and rising inflation over the past few years in Taiwan, Indonesia intends to propose an increase in the minimum wage and overtime wage for Indonesian domestic workers in Taiwan.

\section{Literature review}

The International Labour Organization (2012) said that minimum wage policy should pay attention to the elements of poverty alleviation and ensure the satisfaction and fulfillment of the needs of workers and their families, so that the main concept of the policy of setting the minimum wage is to provide social protection in the form of a fair wage standard for everyone.

As mentioned in the background that the employment policy in force in Indonesia, as well as those in Taiwan has not set and set minimum wage standards Indonesian Migrant Workers Domestic Sector (domestic helper /care giver). However, when referring to the Convention of the International Labour Organization (IL0) No. 189 year 2011 on Domestic Worker convention, article 11 states that:

"Each Member shall take measures to ensure that domestic workers enjoy minimum wage coverage, where such coverage exists, and that remuneration is established without discrimination based on sex". 
Under the convention, domestic workers are also entitled to a minimum wage as big as the existing minimum wage rules for other workers. Article 10 of the convention also mentions the equality of domestic workers with other workers in general matters such as normal working time, calculation of overtime wages, rest periods, leave rights stipulated in national law, and collective regulations.

Research on the minimum wage of migrant domestic workers, especially in Taiwan, has been conducted by several researchers. Hwang, J. T, Wang, C. H., \& Chung, C. P. (2015) in his research revealed that the minimum wage should apply to foreign domestic workers, and foreign domestic workers should not be treated as separate groups of workers in the minimum wage policy. Similarly, Wang, C. H., Chung, C. P., Hwang, J. T., \& Ning, C. Y. (2011) said in their research that there is a gap in treatment between Local Domestic Helpers and Foreign Domestic Workers (Indonesian Migrant Workers) in Taiwan, including in terms of wages provided. Therefore, a number of regional, multilateral and bilateral agreements are required in both the sending and receiving countries, so that a rights-based approach will provide homogenous criteria that will help eliminate transnational variations in terms of wages, gender, and employment agreements (Islam \&Cojocaru, 2015). In addition, Islam \& Cojocaru (2015) in its research also suggested that both sending and receiving countries should ratify and implement the ILO Convention on Decent Employment for Domestic Workers in 2011 (No. 189); CEDAW, and ICCPR.

Although Indonesia and Taiwan have not ratified the ILO convention, the recommendations mentioned in the convention can be a reference used by both parties in the arrangement of the implementation and protection of domestic sector Indonesian Migrant Workers working in Taiwan. The Government of Indonesia can seek to allow the Government of Taiwan to establish a policy of minimum wage standards for domestic sector Foreign Labor that is equal to or at least close to the minimum wage standards of other workers. In addition, the Indonesian government may also request that other wage requirements (such as normal working hours and overtime wages) be adjusted to labor protections/standards set in Taiwan (Labour Standard Act).

\section{Results and discussion}

Taiwan is the destination country of Indonesian Migrant which ranks second only to Malaysia. Indonesian Migrant Workers placed in Taiwan for the purpose to work in various sectors, namely Fishermen's Crew, Manufacturing, Construction, Nursing Home/Hospital Workers, Care Giver, and Maid. Indonesia currently excels in the domestic sector (care giver and maid), while other countries such as Vietnam, Philippines, and Thailand excel in the non-domestic sector (Figure 1). Domestic sector Indonesian Migrant Workers working in Taiwan is dominated by Care Giver. 
International Journal of Innovation, Creativity and Change. www.ijicc.net

Volume 15, Issue 10, 2021

\section{Figure 1. Number of Domestic Workers in Taiwan by Job Title in 2019}

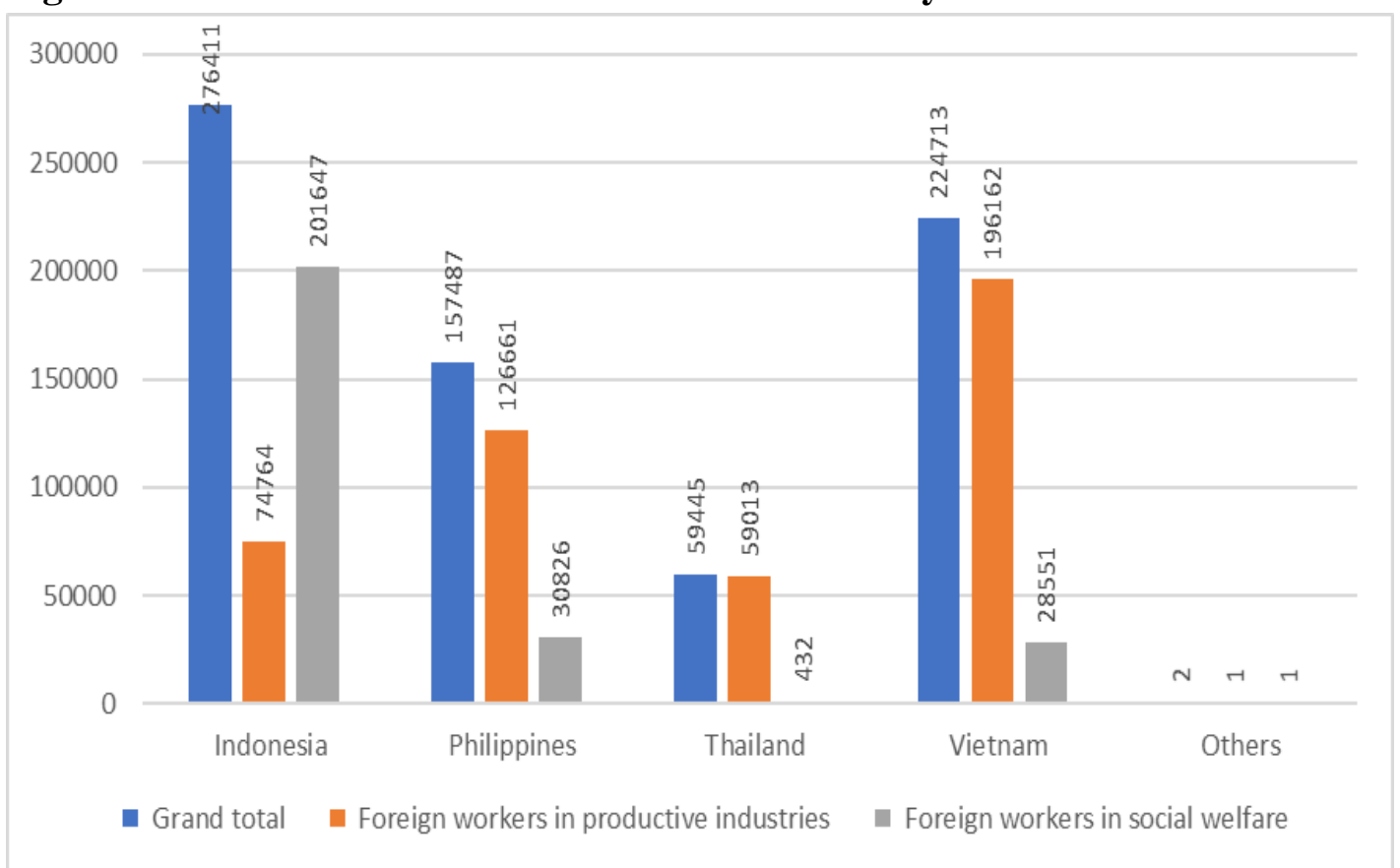

Source: Ministry of Labor, Taiwan (processed)

Indonesian Migrant Workers has a good branding image in the eyes of the people and government of Taiwan. Indonesian Migrant Workers is preferred by Taiwanese employers when it comes to caring for the elderly (Care Giver), in comparison to Filipino, Vietnamese, and Thai workers. The reason for this because female Indonesian Migrant Workers is patient and loyal and does not demand much even though they are vulnerable to exploitation (Loveband 2003, Gusman 2012). In addition, Indonesian Migrant Workers also known to be more diligent, friendly, and loyal despite being less skilled as a nurse (Setyaningsih 2011, Lan 2006). Indonesian Migrant Workers increasingly has a comparative advantage, due to Taiwan's dependence on Indonesian Migrant Workers is quite large. This opportunity needs to be utilized by the Government of Indonesia in order to position higher bargaining power of Indonesian Migrant Workers, for example by raising the minimum wage of domestic sector Indonesian Migrant Workers. 
International Journal of Innovation, Creativity and Change. www.ijicc.net

Volume 15, Issue 10, 2021

Table 1. Comparison of Placement Fee Structure in Several Countries (Rupiah)

\begin{tabular}{|c|c|c|c|c|c|c|c|c|}
\hline \multirow{2}{*}{ Information } & \multicolumn{2}{|c|}{ Taiwan* } & \multicolumn{2}{|c|}{ Hong Kong** } & \multicolumn{2}{|c|}{ Singapore (Java) ${ }^{*+*}$} & \multicolumn{2}{|c|}{ Singapore (Outside Java) } \\
\hline & Per 3 Years & $\begin{array}{c}\text { Per } \\
\text { month }\end{array}$ & Per 2 Years & $\begin{array}{c}\text { Per } \\
\text { month }\end{array}$ & Per 2 Years & $\begin{array}{c}\text { Per } \\
\text { month }\end{array}$ & Per 2 Years & $\begin{array}{c}\text { Per } \\
\text { month }\end{array}$ \\
\hline Wages & 290.657 .160 & 8.073 .810 & 199.163 .856 & 8.298 .494 & 135.606 .636 & 5.650 .277 & 135.606 .636 & 5.650 .277 \\
\hline Placement Fee & 17.925 .400 & 497.928 & 14.730 .000 & 613.750 & 13.538 .000 & $\mathbf{5 6 4 . 0 8 3}$ & 12.397 .000 & 516.542 \\
\hline Passport fee & 355.000 & 9.861 & 355.000 & 14.792 & 355.000 & 14.792 & 355.000 & 14.792 \\
\hline Health Test fee & 670.000 & 18.611 & 670.000 & 27.917 & 670.000 & 27.917 & 670.000 & 27.917 \\
\hline $\begin{array}{l}\text { Accommodation, } \\
\text { Consumption \& } \\
\text { Training fee }\end{array}$ & 7.740 .000 & 215.000 & 5.500 .000 & 229.167 & 4.000 .000 & 166.667 & 4.000 .000 & 166.667 \\
\hline $\begin{array}{l}\text { Competency Test } \\
\text { Institute }\end{array}$ & 250.000 & 6.944 & 250.000 & 10.417 & 250.000 & 10.417 & 250.000 & 10.417 \\
\hline Departure Ticket & 3.185 .000 & 88.472 & - & - & 2.583 .000 & 107.625 & 1.442 .000 & 60.083 \\
\hline Local Transport fee & 200.000 & 5.556 & 200.000 & 8.333 & - & - & - & - \\
\hline $\begin{array}{l}\text { Corporate Services } \\
\text { fee }\end{array}$ & 4.069 .400 & 113.039 & 3.707 .000 & 154.458 & 3.310 .000 & 137.917 & 3.310 .000 & 137.917 \\
\hline Agency Services fee & - & - & 678.000 & 28.250 & - & - & - & - \\
\hline Service Fee & 38.763 .787 & 1.076 .772 & - & - & - & - & - & - \\
\hline MCU & 3.799 .440 & 105.540 & - & - & - & - & - & - \\
\hline $\mathrm{ARC}$ & 1.424 .790 & 39.578 & - & - & - & - & - & - \\
\hline Health Insurance & 5.043 .757 & 140.104 & - & - & - & - & - & - \\
\hline Agency Fee & 28.495 .800 & 791.550 & - & - & - & - & - & - \\
\hline Net Wages & 233.967 .973 & 6.499 .110 & 184.433 .856 & 7.684 .744 & 122.068 .636 & 5.086 .193 & 123.209 .636 & 5.133 .735 \\
\hline $\begin{array}{l}\text { Net Wages Per } \\
\text { Year }\end{array}$ & \multicolumn{2}{|c|}{77.989 .324} & \multicolumn{2}{|c|}{92.216 .928} & \multicolumn{2}{|c|}{61.034 .318} & \multicolumn{2}{|c|}{61.604 .818} \\
\hline
\end{tabular}

Source:

*Statement of Indonesian Migrant Worker Candidate, domestic worker placement fee to Taiwan (BPPMI) applicable wage NT\$17,000, with total cost of Taiwan service for 3 years MCU (NT\$8,000), ARC (NT\$3,000), Health Insurance (NT\$10,620), Agency Fee $(\mathrm{NT} \$ 60,000)$

**Statement of Indonesian Migrant Worker Candidate, domestic worker placement fee to Hongkong (BPPMI), wage valid at SGD 550

***Statement of Indonesian Migrant Worker Candidate, domestic worker placement fee to Singapore (BPPMI), applicable wage HKD 4,520

Note:

$\checkmark$ Taiwan Dollar - Indonesian Rupiah conversion rate as of February 29, 2020 is Rp.475

$\checkmark \quad$ Singapore Dollar - Indonesian Rupiah conversion rate as of 29 February 2020 is Rp.10.273

$\checkmark$ Hong Kong Dollar - Indonesian Rupiah conversion rate as of February 29, 2020 is Rp.1.836

The domestic sector Indonesian Migrant Workers Minimum Wage in Taiwan is not low compared to other placement countries such as Hong Kong, Singapore, and the Middle East. However, the placement costs incurred by Indonesian Migrant Workers for Taiwan are higher 
International Journal of Innovation, Creativity and Change. www.ijicc.net

Volume 15, Issue 10, 2021

compared to the Indonesian Migrant Workers of other placement countries such as Hongkong and Singapore (Table. 1). Indonesian Migrant Workers working in the Middle East, does not even cost money. Table 1 shows that some components of placement fees between multiple placement countries are the same, but there are some striking differences in placement fee components: Indonesian Migrant Workers in Taiwan is charged visa fees while Hong Kong and Singapore are not charged; accommodation, consumption and training costs in Taiwan are higher than Hong Kong and Singapore; the cost of departure tickets in Taiwan and Singapore is borne by prospective Indonesian Migrant Workers, while Hong Kong is borne by the employer; and the cost of corporate services in Taiwan is higher compare to Hong Kong and Singapore where the company's service costs should not exceed one month's Indonesian Migrant Workers salary. In addition, Indonesian Migrant Workers for Taiwan also has to spend the service cost in Taiwan such as medical checkup, Allien Residence Certificate (ARC), health insurance, and service agencies fee, while other placement countries Indonesian Migrant Workers does not have to spend service costs. Looking at the cost structure, it is appropriate that the minimum wage in the domestic sector increases.

Table 2. Comparison of Cost Structure of Domestic sector Indonesian Migrant Workers Placement and Taiwan Non-Domestic Sector Indonesian Migrant Workers (NT\$)

\begin{tabular}{|l|r|r|r|r|}
\hline \multirow{2}{*}{ Information } & \multicolumn{2}{|c|}{ Non Domestic } & \multicolumn{2}{c|}{ domestic } \\
\cline { 2 - 5 } & Per 3 Years & Per month & \multicolumn{1}{c|}{ Per 3 Years } & \multicolumn{1}{c|}{ Per month } \\
\hline Wages & 856.800 & 23.800 & 612.000 & 17.000 \\
\hline Placement Fee & 31.047 & 862 & 37.743 & 1.048 \\
\hline Passport fee & 747 & 21 & 747 & 21 \\
\hline Health Test fee & 1.411 & 39 & 1.411 & 39 \\
\hline $\begin{array}{c}\text { Accommodation, Consumption \& } \\
\text { Training }\end{array}$ & 7.370 & 205 & 16.297 & 453 \\
\hline Competency Test Institute & - & - & 526 & 15 \\
\hline VISA & 1.946 & 54 & 1.946 & 54 \\
\hline Protection Insurance & 1.120 & 31 & 1.120 & 31 \\
\hline Departure Ticket & 6.706 & 186 & 6.706 & 186 \\
\hline Local Transport fee & 421 & 12 & 421 & 12 \\
\hline Corporate Services fee & 11.326 & 315 & 8.568 & 238 \\
\hline Service Charge** & 188.792 & 5.244 & 81.620 & 2.267 \\
\hline MCU & 8.000 & 222 & 8.000 & 222 \\
\hline ARC & 3.000 & 83 & 3.000 & 83 \\
\hline Health Insurance & 11.160 & 310 & 10.620 & 295 \\
\hline Labor Social Insurance & 16.632 & 462 & & - \\
\hline Agency Fee & 60.000 & 1.667 & 60.000 & 1.667 \\
\hline Meal Fee & 90.000 & 2.500 & & - \\
\hline Net Wages (NTS) & 636.961 & 17.693 & 492.637 & 13.684 \\
\hline Net Wages (Rupiah) & 302.512 .039 & 8.403 .112 & 233.967 .973 & 6.499 .110 \\
\hline
\end{tabular}

Source: Statement of Indonesian Migrant Worker Candidate placement fee to Taiwan (BPPMI) Note: Taiwan Dollar - Indonesian Rupiah conversion rate as of February 29, 2020 is Rp.475 


\section{Wages in force in 2020}

On the other hand, there is a significant difference in comparison between domestic sector Indonesian Migrant Workers wages and non-domestic sector Indonesian Migrant Workers. The amount of domestic Indonesian Migrant Workers wages is smaller which is 71 percent of nondomestic Indonesian Migrant Workers wages. Not much different from the comparison of net wages (after deducting placement costs and service costs) received, namely net wages received by the domestic sector Indonesian Migrant Workers of 77 percent against the wages of nondomestic sector Indonesian Migrant Workers.

A study in Taiwan found that there are some differences in treatment between Local Domestic Helpers (maid) and foreign domestic workers (Indonesian Migrant Workers) in Taiwan. When viewed in terms of local domestic worker wages are higher by NT\$ $1200-2500$. While foreign domestic workers wages amounted to NT\$ 566. Another difference is that foreign domestic workers do not have normal working hours and may not have annual leave, job description is not clear, it is required to stay with the employer because they have to be on standby to work around the clock and domestic workers should not move to other employers except for legal reasons and employer permits.

Table 3. Comparison of Working Conditions of Local Domestic Workers with Foreign Domestic Workers in Taiwan

\begin{tabular}{|l|l|l|}
\hline \multicolumn{1}{|c|}{ information } & \multicolumn{1}{|c|}{$\begin{array}{c}\text { Local Domestic Workers } \\
\text { (Domestic workers and caregivers) }\end{array}$} & $\begin{array}{l}\text { Foreign Domestic Workers } \\
\text { (Domestic workers and caregivers) }\end{array}$ \\
\hline Wages & $\begin{array}{l}\text { High } \\
\text { NTS 1.200-NTS 2.500 Per Hari }\end{array}$ & $\begin{array}{l}\text { Low } \\
566 \mathrm{NTS} \text { Per Hari }\end{array}$ \\
\hline Leave & $\begin{array}{l}\text { Normal, } \\
\text { Working hours are unclear }\end{array}$ & $\begin{array}{l}\text { Abnormal, } \\
\text { May not have year-round leave }\end{array}$ \\
\hline Job & $\begin{array}{l}\text { Clearly defined, } \\
\text { Employers tend to ask them to do } \\
\text { additional work. }\end{array}$ & $\begin{array}{l}\text { Not clearly defined, } \\
\text { Often asked to serve as a maid, } \\
\text { caregiver, and even employee }\end{array}$ \\
\hline $\begin{array}{l}\text { Accomodation } \\
\text { Not required to live with an } \\
\text { employer }\end{array}$ & $\begin{array}{l}\text { It is necessary to stay with the } \\
\text { employer and so potentially to } \\
\text { work or be on standby at all times }\end{array}$ \\
\hline $\begin{array}{l}\text { Employer } \\
\text { transfer }\end{array}$ & $\begin{array}{l}\text { Have the freedom to move to } \\
\text { another employer with a greater } \\
\text { degree of autonomy. }\end{array}$ & $\begin{array}{l}\text { It is not permissible to move to } \\
\text { another employer except for legal } \\
\text { reasons or with the employer's } \\
\text { permission. }\end{array}$ \\
\hline
\end{tabular}

Source: Ministry of Labor, Taiwan (R.O.C.), dalam Wang, 2018 
International Journal of Innovation, Creativity and Change. www.ijicc.net

Volume 15, Issue 10, 2021

\section{Minimum Wage}

Comparison of Domestic Indonesian Migrant Workers Minimum Wage with Taiwan NonDomestic Indonesian Migrant Workers

Based on the calculation, the minimum wage of non-domestic sector workers is determined by the Taiwanese government based on the Consumer Price Index (CPI), while the increase in the minimum wage of domestic sector workers is determined based on the results of bilateral agreements between the sending countries and Taiwan. Although informal workers have reduced housing costs and consumption that employers already bear, unclear working hours coupled with heavier workloads needs to get serious attention in the calculation of the minimum wage.

Figure 2 shows from 1997 to 2006 there are similarities between the wages of domestic workers and non-domestic workers in Taiwan which is NT\$15,840. In 2007 the wages of non-domestic workers increased to 17,280 , in 2012 it rose again to NT\$18,780 and continued to increase periodically every year, with wages as of January 2020 amounting to NT\$23,800. Between 1997 and 2020 domestic workers' wages have only increased once to NT\$17,000 in 2015, and have not increased in the last 5 years. This data shows that there is a wage gap between domestic workers and non-domestic workers in Taiwan.

Figure 2. Domestic Indonesian Migrant Workers wage growth and Taiwan NonDomestic Indonesian Migrant Workers 1997-2020

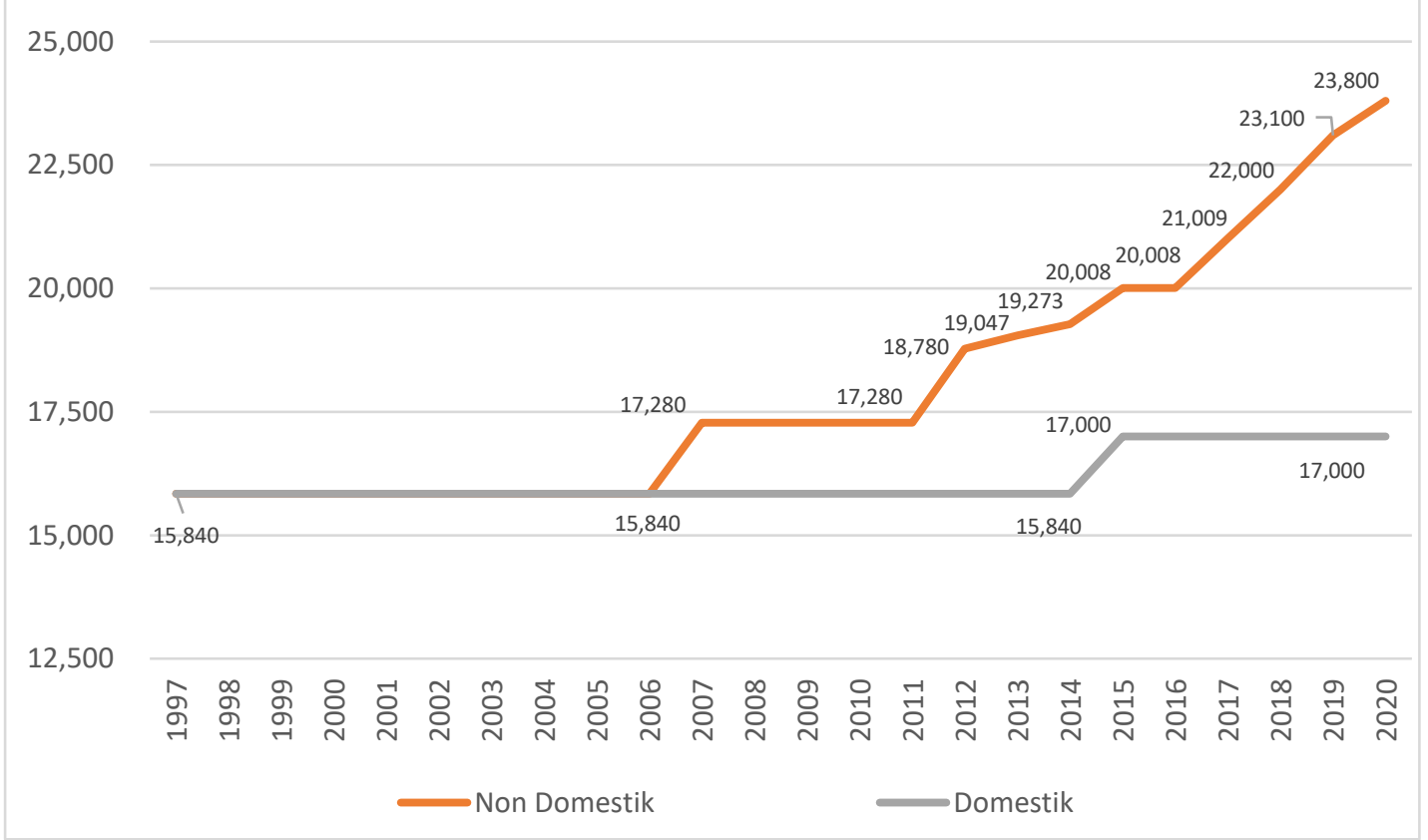

Source: tradingeconomics.com|council of labour affairs, downloaded on 13 February 2020 
International Journal of Innovation, Creativity and Change. www.ijicc.net

Volume 15, Issue 10, 2021

\section{Estimation of Indonesian Migrant Workers Minimum Wage in Taiwan}

In this study, the estimation of minimum wage using prorate approach, namely domestic Indonesian Migrant Workers wage, was calculated using Taiwan's minimum wage increase growth approach starting from 2016 - 2020 (Estimated I). Table 4 shows that over the past 4 years, Taiwan's minimum wage has increased by 5\% every year from 2017 to 2019 and an increase of $3 \%$ in 2020. If it follows the growth of the minimum wage every year, then in 2020 the domestic sector Indonesian Migrant Workers wage will be 20,222. In detail, it can be seen in Table 4.

Table 4. Domestic Indonesian Migrant Workers Wage Estimates Follow the Pace Taiwan Minimum Wage Growth

\begin{tabular}{|c|c|c|c|c|}
\hline Year & $\begin{array}{c}\text { Minimum Wage } \\
\text { Taiwan }\end{array}$ & $\begin{array}{c}\text { Current Domestic Wages } \\
\text { (NT\$) }\end{array}$ & $\begin{array}{c}\text { Taiwan Minimum } \\
\text { Wage Growth (\%) }\end{array}$ & $\begin{array}{c}\text { Estimation I } \\
\text { (NT\$) }\end{array}$ \\
\hline 2015 & 20.008 & 17.000 & - & 17.000 \\
\hline 2016 & 20.008 & 17.000 & 5 & 17.000 \\
\hline 2017 & 21.009 & 17.000 & 5 & 17.851 \\
\hline 2018 & 22.000 & 17.000 & 5 & 19.693 \\
\hline 2019 & 23.100 & 17.000 & 3 & 20.222 \\
\hline 2020 & 23.800 & 17.000 & & 5 \\
\hline
\end{tabular}

Source: Ministry of Labour, Taiwan (processed data)

In addition, the study also conducted an Indonesian Migrant Workers Minimum Wage Estimation by following the increase in the average CPI growth value of Taiwan (Estimated II). The average CPI growth used was from 2015 to 2018 which is $3.4 \%$. The calculation resulting in the wage value of domestic sector Indonesian Migrant Workers in 2020 is NT\$ 20,093. This value is not much different from the previous method. Detailed information can be found in Table 5 . 
International Journal of Innovation, Creativity and Change. www.ijicc.net

Volume 15, Issue 10, 2021

Table 5. Domestic Indonesian Migrant Workers Wage Estimates Follow Average Increase Taiwan CPI growth rate

\begin{tabular}{|c|c|c|c|c|}
\hline Year & $\begin{array}{c}\text { Minimum Wage } \\
\text { Taiwan }\end{array}$ & $\begin{array}{c}\text { Current Domestic } \\
\text { Wages } \\
\text { (NT\$) }\end{array}$ & $\begin{array}{c}\text { Average CPI Growth } \\
\text { in Taiwan* }\end{array}$ & $\begin{array}{c}\text { Estimation II } \\
\text { (NT\$) }\end{array}$ \\
\hline 2015 & 20.008 & 17.000 & \multirow{2}{*}{$3,4 \%$} & 17.000 \\
\hline 2016 & 20.008 & 17.000 & 17.578 \\
\hline 2017 & 21.009 & 17.000 & & 18.176 \\
\hline 2018 & 22.000 & 17.000 & & 19.794 \\
\hline 2019 & 23.100 & 17.000 & & 20.093 \\
\hline 2020 & 23.800 & 17.000 & \\
\hline
\end{tabular}

Source: Ministry of Labour, Taiwan (processed data)

$* 4^{\text {th }}$ JTF meeting minutes

To analyze the comparison between the estimated wages of domestic Indonesian Migrant Workers using the above two methods (Table 4 and Table 5) with the development of domestic and non- Indonesian Migrant Workers over the last 5 years, can be seen in the following figure: 
International Journal of Innovation, Creativity and Change. www.ijicc.net

Volume 15, Issue 10, 2021

Figure 3. Taiwan domestic Indonesian Migrant Workers wage estimate

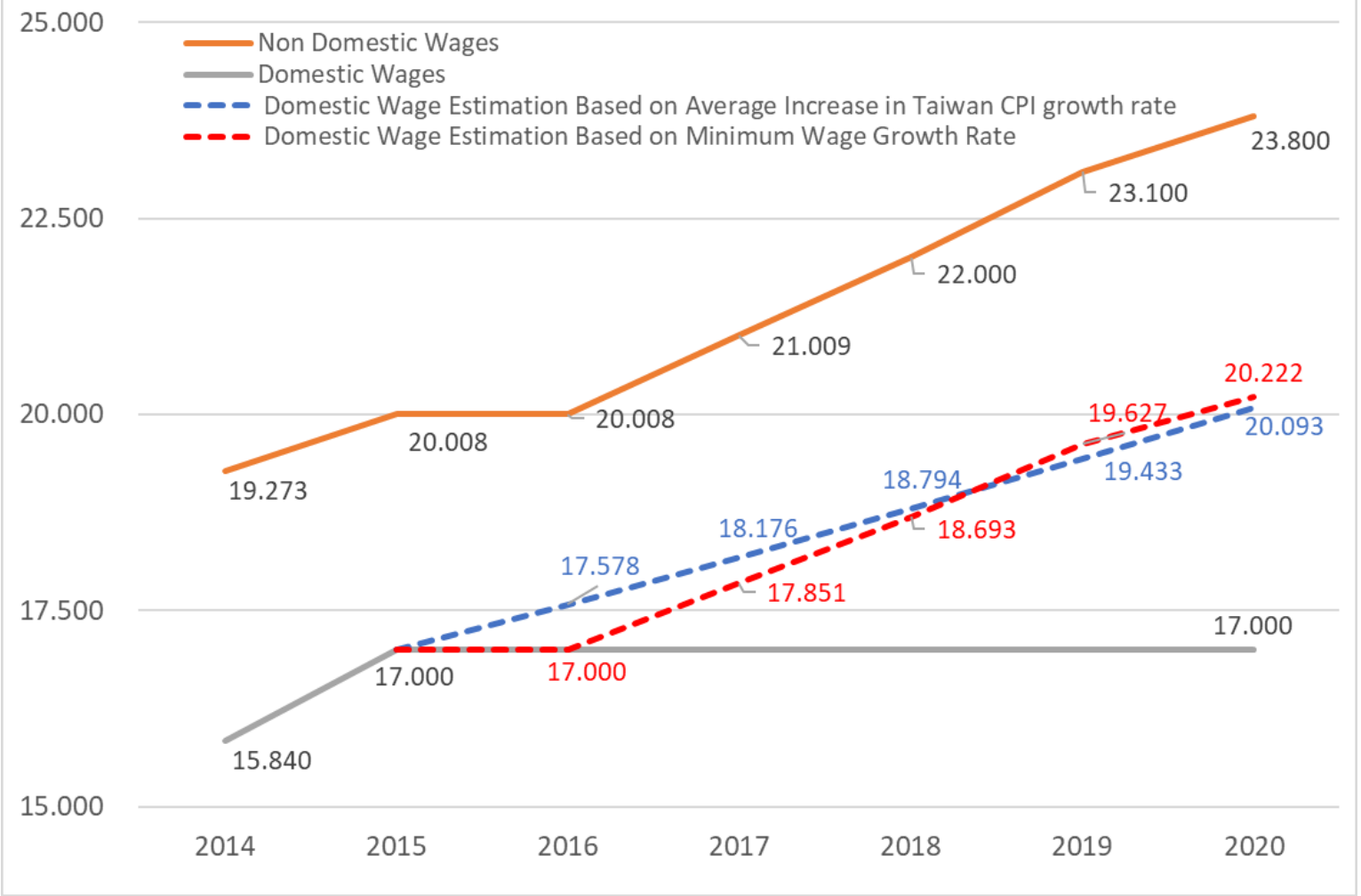

Source: Ministry of Labour, Taiwan (processed data)

After the wage estimate, the next stage of this study is to see how much net wages received by domestic Indonesian Migrant Workers if wages are raised to the amount according to the calculation made. Thus, it will be able to see how much the wage gap reduction between domestic Indonesian Migrant Workers and non-domestic Indonesian Migrant Workers will be.

Table 6 shows comparison between the net wages of the domestic Indonesian Migrant Workers and the current non-domestic Indonesian Migrant Workers, with the net wages of the domestic Indonesian Migrant Workers using estimated result. Net wages of non-domestic Indonesian Migrant Workers per month after being converted into rupiah currency amounted to Rp.8.40 million while the net wage of domestic Indonesian Migrant Workers is currently Rp.6.49 million. In other words, the wages obtained by the domestic Indonesian Migrant Workers are 77.27 percent of non-domestic Indonesian Migrant Workers wages. After the first estimated result based on Taiwan's average minimum wage growth rate, the proportion of domestic Indonesian Migrant Workers wages grew to 95.53 percent or Rp. 8.03 million. Not much different from the second estimated result that refers to Taiwan's average CPI growth of 3.4 percent, with a net wage yield of Rp.7.97 million or 94.78 percent against the net wage of nondomestic Indonesian Migrant Workers. By increasing the domestic Indonesian Migrant 
International Journal of Innovation, Creativity and Change. www.ijicc.net

Volume 15, Issue 10, 2021

Workers wage, it will reduce the gap between non-domestic Indonesian Migrant Workers net wages and domestic Indonesian Migrant Workers.

Table 6. Comparison of Net Wages of Domestic Indonesian Migrant Workers with Non-Domestic Indonesian Migrant Workers After Wage Adjustment (NT\$)

\begin{tabular}{|c|c|c|c|c|c|c|c|c|}
\hline \multirow{2}{*}{ Information } & \multicolumn{2}{|c|}{ Non-Domestic } & \multicolumn{2}{|c|}{ Domestic } & \multicolumn{2}{|c|}{ Estimation $I^{*}$} & \multicolumn{2}{|c|}{ Estimation II $^{* 8}$} \\
\hline & Per 3 Years & Per month & Per 3 Years & Per month & Per 3 Years & Per month & Per 3 Years & Per month \\
\hline Wages & 856.800 & 23.800 & 612.000 & 17.000 & 727.992 & 20.222 & 723.348 & 20.093 \\
\hline PlacementFee & 31.047 & 862 & 37.743 & 1.048 & 37.743 & 1.048 & 37.743 & 1.048 \\
\hline Passport fee & 747 & 21 & 747 & 21 & 747 & 21 & 747 & 21 \\
\hline Health Test Fee & 1.411 & 39 & 1.411 & 39 & 1.411 & 39 & 1.411 & 39 \\
\hline $\begin{array}{l}\text { Accommodation, } \\
\text { Consumption } \\
\text { \& Training }\end{array}$ & 7.370 & 205 & 16.297 & 453 & 16.297 & 453 & 16.297 & 453 \\
\hline $\begin{array}{l}\text { Test Institute } \\
\text { Competence }\end{array}$ & - & - & 526 & 15 & 526 & 15 & 526 & 15 \\
\hline VISA & 1.946 & 54 & 1.946 & 54 & 1.946 & 54 & 1.946 & 54 \\
\hline Protection Insurance & 1.120 & 31 & 1.120 & 31 & 1.120 & 31 & 1.120 & 31 \\
\hline Departure Ticket fee & 6.706 & 186 & 6.706 & 186 & 6.706 & 186 & 6.706 & 186 \\
\hline Local Transport fee & 421 & 12 & 421 & 12 & 421 & 12 & 421 & 12 \\
\hline Corporate Services fee & 11.326 & 315 & 8.568 & 238 & 8.568 & 238 & 8.568 & 238 \\
\hline Service Fee & 188.792 & 5.244 & 81.620 & 2.267 & 81.620 & 2.267 & 81.620 & 2.267 \\
\hline MCU & 8.000 & 222 & 8.000 & 222 & 8.000 & 222 & 8.000 & 222 \\
\hline$\overline{A R C}$ & 3.000 & 83 & 3.000 & 83 & 3.000 & 83 & 3.000 & 83 \\
\hline HealthInsurance & 11.160 & 310 & 10.620 & 295 & 10.620 & 295 & 10.620 & 295 \\
\hline $\begin{array}{l}\text { Labour Socual } \\
\text { Insurance }\end{array}$ & 16.632 & 462 & & - & & - & & - \\
\hline Agency Fee & 60.000 & 1.667 & 60.000 & 1.667 & 60.000 & 1.667 & 60.000 & 1.667 \\
\hline Meal Fee & 90.000 & 2.500 & & - & & - & & - \\
\hline Net Wages (NTS) & 636.961 & 17.693 & 492.637 & 13.684 & 608.629 & 16.906 & 603.985 & 16.777 \\
\hline Net Wages (Rupiah) & 302.512 .039 & 8.403 .112 & 233.967 .973 & 6.499 .110 & 289.056 .054 & 8.029 .335 & 286.850 .479 & 7.968 .069 \\
\hline
\end{tabular}

Note:

Taiwan Dollar Convertible - Indonesian Rupiah February 29, 2020 is Rp.475

*Wage value based on Taiwan's minimum wage growth approach (data in process)

**Wage value based on Taiwan's average CPI growth in 2015 to 2018 of 3.4\% (current data)

\section{Overtime Wages}

Domestic sector Indonesian Migrant Workers overtime wages in Taiwan are still very low with unregulated overtime hours. So far, domestic sector Indonesian Migrant Workers that uses its weekly break time to work overtime only gets overtime wage compensation of NT\$567/day which is equal to the daily wage of domestic sector Indonesian Migrant Workers (NT\$17,000 : 30 days). This is not worth the weekly rest time they have to sacrifice for work. The overtime wage compensation they earn should be greater than the daily wages they earn at work. 
International Journal of Innovation, Creativity and Change. www.ijicc.net

Volume 15, Issue 10, 2021

In his research, Wang, 2018 (Table 3) showed that overtime wage compensation obtained by domestic sector Indonesian Migrant Workers is much lower when compared to daily wages earned by local domestic workers. In fact, if an employer uses the services of a local domestic worker at the time of Indonesian Migrant Workers is on weekly break, the employer must pay the local domestic worker at least NT\$1,200. The figure is twice as high as the overtime wage compensation obtained by the Domestic sector Indonesian Migrant Workers.

When compared to the working time provisions and overtime wage calculations applicable to non-domestic workers in Taiwan, domestic sector Indonesian Migrant Workers overtime wages are much lower with higher working time.

Calculation of Overtime Wages of Domestic Indonesian Migrant Workers and Current NonDomestic Indonesian Migrant Workers

The current domestic Indonesian Migrant Workers overtime wage is calculated in prorate, namely the monthly wage divided by the number of days per month. In the cooperation agreement it is written that overtime is 1 time a week with a maximum of 4 times a month. As for non-domestic Indonesian Migrant Workers, overtime wage calculation is calculated per hour with a maximum of 4 hours per day and a maximum of 54 hours per month or no more than 138 hours per three months. Provisions on non-domestic Indonesian Migrant Workers overtime wages are stipulated in Taiwan Employment Law Articles 24, 32, and 36. However, this does not apply to domestic Indonesian Migrant Workers.

The following simulation of overtime wage calculation uses the current minimum wage, with a domestic Indonesian Migrant Workers minimum wage of NT\$17,000 and a non-domestic Indonesian Migrant Workers minimum wage of NT\$23,800. 
Table 7. Simulation of Taiwan's Current Indonesian Migrant Workers Overtime Wage Calculation

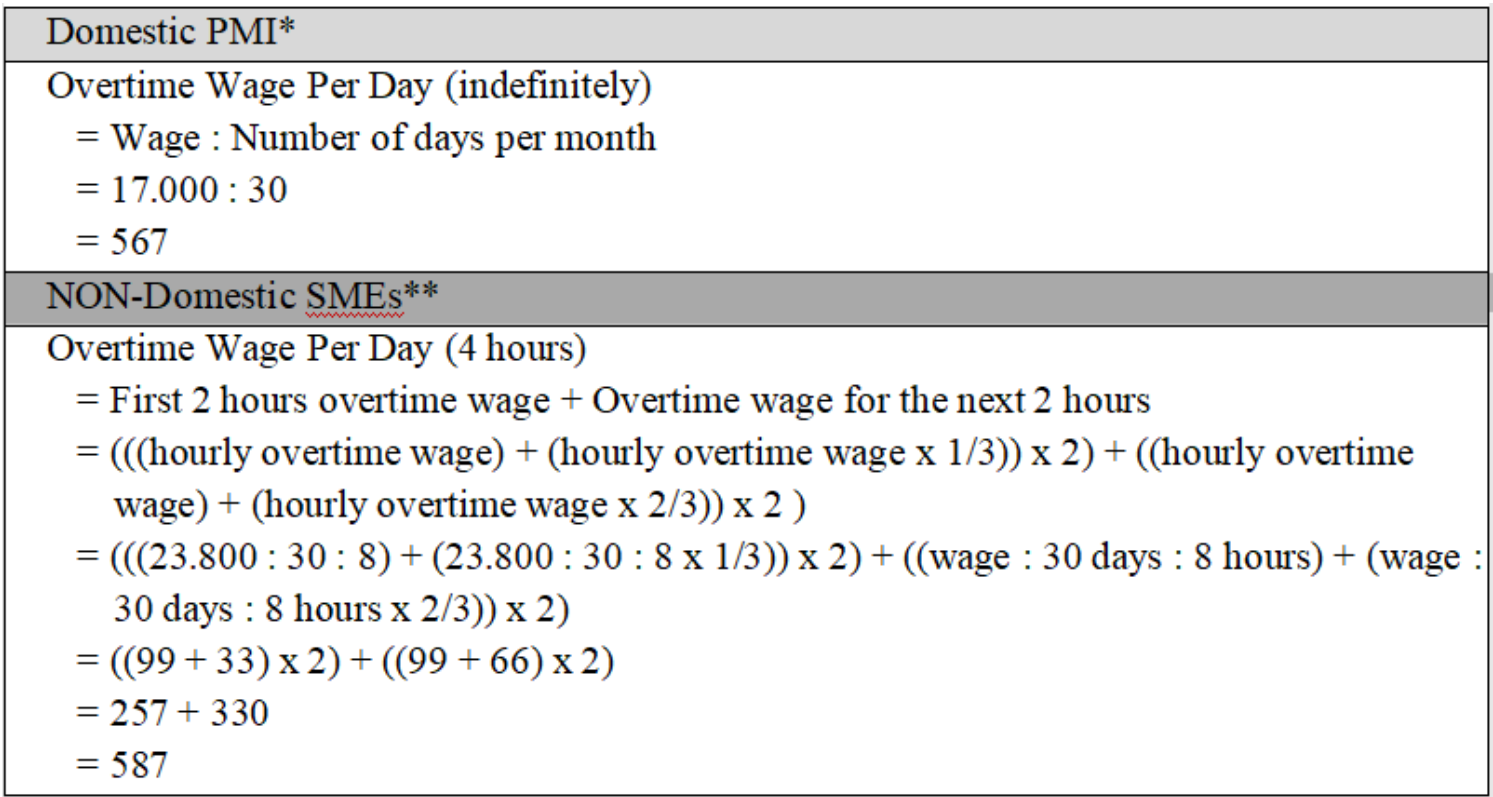

Source:

*Statement of Indonesian Migrant Worker Candidate placement fee to Taiwan (BPPMI)

**Labor Standard Act Taiwan

\section{Estimated Overtime Wages Indonesian Migrant Workers domestic sector}

The estimated value of domestic Indonesian Migrant Workers overtime wages in this study is calculated by following the rules applicable in the Taiwan Labor Standard Act Articles 24, 32, and 36. In other words, this calculation uses the same calculation as Taiwan's non-domestic Indonesian Migrant Workers overtime wage calculation. The calculation of domestic Indonesian Migrant Workers overtime wages is done on the basis of the minimum wage that has previously been calculated through two methods. The results of the calculation are as follows: 
International Journal of Innovation, Creativity and Change. www.ijicc.net

Volume 15, Issue 10, 2021

Table 8. Calculation of Overtime Wages Indonesian Migrant Workers Domestic Sector Refers on The Calculation of Overtime Wages of Taiwan Non-Domestic Indonesian Migrant Workers

\begin{tabular}{|l|c|c|}
\hline \multirow{2}{*}{\multicolumn{1}{|c|}{ information }} & \multicolumn{2}{c|}{ Estimated Overtime Wages } \\
\cline { 2 - 3 } & Estimation I & Estimation II \\
\hline Estimated Domestic PMI Wages & 20.222 & 20.093 \\
\hline Number of days per month & 30 & 30 \\
\hline Working hours per day & 8 & 8 \\
\hline Overtime wage per hour* & 84 & 84 \\
\hline First 2-hour overtime wage ( $\leq 2$ hours)** & 225 & 223 \\
\hline $\begin{array}{l}\text { Overtime wages above 2 hours }(>2 \text { and } \leq 8 \\
\text { hours))*** }\end{array}$ & 843 & 837 \\
\hline Overtime wages per day $(\geq 8$ hours)**** & 1.067 & 1.060 \\
\hline Overtime wages per month (4 days/month)***** & 4.269 & 4.242 \\
\hline
\end{tabular}

Note:

Calculation refers to Labour Standard Art Taiwan Articles 24.32, and 36

Overtime wages are calculated assuming 8 hours of working hours per day

*Wages / Number of days per month / Hours worked per day

$* *($ Overtime wage per hour $+($ Hourly overtime wage $\mathrm{x} 1 / 3)) \times 2$

(Hourly overtime wage $+($ hourly overtime wage $\mathrm{x} 2 / 3))$ x 6

First 2 hours overtime wage + Overtime wage above 2 hours

Overtime wages per day x Number of holidays per month

To calculate the maximum overtime wage of Taiwan's domestic Indonesian Migrant Workers, another alternative that can be done is to calculate the average overtime wage of domestic Indonesian Migrant Workers per hour, then multiplied by the maximum overtime time per month (54 hours). Then the total overtime wage per month is divide by the number of holidays per month (4 days), so that the results are obtained as follows:

Table 9. Taiwan Domestic Indonesian Migrant Workers Maximum Overtime Wage Calculation

\begin{tabular}{|l|c|c|}
\hline \multirow{2}{*}{\multicolumn{1}{|c|}{ information }} & \multicolumn{2}{c|}{$\begin{array}{c}\text { Estimated Overtime Wage } \\
\text { (Maximum) }\end{array}$} \\
\cline { 2 - 3 } & Estimation I & Estimation II \\
\hline Estimated Domestic PMI Wages & 20.222 & 20.093 \\
\hline Number of days per month & 30 & 30 \\
\hline Working hours per day & 8 & 8 \\
\hline Overtime wage per hour* & 84 & 84 \\
\hline Monthly overtime wages (54 hours)** & 4.550 & 4.521 \\
\hline Overtime wages per day (4x per month)*** & 1.137 & 1.130 \\
\hline
\end{tabular}


International Journal of Innovation, Creativity and Change. www.ijicc.net

Volume 15, Issue 10, 2021

Note:

Maximum overtime wage of 54 hours per month refers to Labour Standard Art Taiwan

Maximum overtime wage calculated assuming total overtime of 54 hours per month

*Wages / Number of days per month / Hours worked per day

**Overtime wage per hour x 54 hours

\section{Overtime wages per month / Number of holidays per month}

Under Taiwan's Labor Law, the maximum allowed overtime time is 54 hours per month. From the calculation above obtained overtime wages per hour of NT $\$ 84$, so that the monthly overtime wage obtained in NT $\$ 4,550$, assuming in one month there are 4 holidays and Indonesian Migrant Workers work on the holiday, then the average wage earned in one day is NT \$ 1,137 .

Based on the above calculations, the recommended overtime wage per day for Taiwan domestic Indonesian Migrant Workers is NT\$1,067 to NT\$1,137.

\section{Conclusion}

1. If the calculation of domestic Indonesian Migrant Workers wages in Taiwan by following the growth rate of Taiwan's minimum wage from 2015 to 2019 is 5 percent and in 2020 by 3 percent, it is estimated that in 2020 domestic Indonesian Migrant Workers wages will reach NT\$ 20,222 ;

2. If the wage increase follows Taiwan's average CPI growth rate in 2015 to 2020 of $3.4 \%$, the domestic Indonesian Migrant Workers wage per year is expected to increase by $3.4 \%$ percent per year, then by that calculation will result in the minimum wage of domestic workers in 2020 of NT\$20,093;

3. The estimated daily overtime wage of domestic Indonesian Migrant Workers in 2020 based on the calculation of non-domestic Indonesian Migrant Workers overtime wages referring to the Taiwan Labor Law is NT\$1,067 (estimated I), NT\$1,060 (estimated II) with a maximum wage in a month of NT\$4,550.

\section{Acknowledgement}

This work was supported by the Manpower Research and Development Center, Ministry of Manpower. 
International Journal of Innovation, Creativity and Change. www.ijicc.net

Volume 15, Issue 10, 2021

\section{REFERENCES}

$\begin{array}{lllll}\text { Domestic } & \text { Worker } & \text { Convention, } & 2011 & \text { (No. }\end{array}$ http;//www.ilo.org/dyn/normlex/en/f?p=NORMLEXPUB:12100:0::NO::p12100_instrumen t_id:2551460

Gusman, Y. (2012). The spiritual life of Indonesia migrant workers in Taiwan (2009-2011). Thesis for master's program at College of Liberal Art, English Department. National Central University.

Hwang, J. T., Wang, C. H., \& Chung, C. P. (2011). Is it possible to decouple foreign workers wages from the minimum wage in Taiwan? The Economic and Labour Relations Review, 22(2), 107-130.

Indonesian Trade and Economic Office Taipei. (2018). Standardization of wages of informal sector Indonesian Migrant Workers in Taiwan.

International Labour Organization (2012). Domestic workers across the world: Global and regional statistics and extent of legal protection (Geneva). https://www.ilo.org/wcmsp5/groups/public/---dgreports/---dcomm/--publ/documents/publication/wcms_173363.pdf

International Labour Organization (2012). Effective protection for domestic workers: a guide to designing labour laws (Geneva). https://www.ilo.org/wcmsp5/groups/public/---dgreports/--dcomm/---publ/documents/publication/wcms_173365.pdf

Islam, R., Cojocaru,S. (2015). Migrant Domestic Workers in Asia: Transnational Variations and Policy Concerns. International Migration for Migration (IOM).

Kong.http://www.cityu.edu.hk/searc/Resources/Paper/WP43_03_Loveband.pdf. Retrieved October 2, 2016.

Lan, P. C. (2003). Political and Social Geography of Marginal Insiders: Migrant Domestic Workers in Taiwan. Asian and Migration Journal, Vol. 12, 1-2, 2003.

Lan, P. C. (2006). Global cinderellas: migrant domestics and newly rich employers in Taiwan. Durham and London: Duke University Press.

Lemos, S. (2007). Minimum wage effects across the private and public sectors in Brazil. Journal of Development Studies, 43(4), 700-720.

Loveband, A. (2003). Positioning the product: Indonesian migrant women workers in contemporary Taiwan. Working Papers Series No. 43 April 2003. Southeast Asia Research Center.City University of Hong.

Ostbye, T., Malhotra, R., Malhotra, C., Arambepola, C., \& Chan, A. (2013). Does support from foreign domestic workers decrease the negative impact of informal caregiving? Results from Singapore survey on informal caregiving. Journals of Gerontology, Series B: Psychological Sciences and Social Sciences, 68(4), 1-13.

Sabban, R. (2002). United Arab Emirates: Migrant women in the United Arab Emirates. The case of female domestic workers (GENPROM Working Paper No. 10). Geneva: ILO. 
Setyaningsih, R. P. (2011). Job satisfaction of Indonesian workers in Taiwan.Thesis untuk program master di International Master's Program in Asia Pacific Studies (IMAS), National Chengchi University (NCCU), Taiwan.

Stigler, G. (1946). The economics of minimum wage legislation. American Economic Review, 36(3), 358-365.

Taiwan Ministry of Manpower. (2020). Foreign workers in productive Industries social welfare sector by various types and nationality. http://statdb.mol.gov.tw/html/mon/c12030.htm. Retrieved 07 February 2020.

Tradingeconomics.com. (2020). Taiwan Minimum Monthly Wage. https://tradingeconomics.com/taiwan/minimum-wages. Retrieved 13 February 2020.

Wang, C. H., Chung, C. P., Hwang, J. T., \& Ning, C. Y. (2011). The Foreign Domestic Workers in Singapore, Hong Kong, and Taiwan: Should Minimum Wage Apply to Foreign Domestic Workers?. The Chinese Economic, 51:2, 154-174.

Wang, J., \& Gunderson, M. (2010). Minimum wage impact in China: Estimation from a prospecified research design 2000-2007. Contemporary Economic Policy, 29(3), 392-406. 